\title{
BUILDING A GLOBAL SYSTEM OF SYSTEMS FOR THE COASTAL OCEAN: A STRATEGIC ACTION PLAN FOR IMPLEMENTING THE COASTAL MODULE OF GOOS
}

\author{
Tom Malone ${ }^{(1)}$, Paul DiGiacomo ${ }^{(2)}$, Jose Muelbert ${ }^{(3)}$, John Parslow ${ }^{(4)}$, Neville Sweijd ${ }^{(5)}$, \\ Tetsuo Yanagi ${ }^{(6)}$, Helen Yap ${ }^{(7)}$, and Bruno Blanke ${ }^{(8)}$ \\ ${ }^{(1)}$ Horn Point Laboratory, UMCES (University of Maryland, Center for Environmental Science), \\ 2020 Horns Point Road, Cambridge, MD 21613 USA, Email: malone@umces.edu

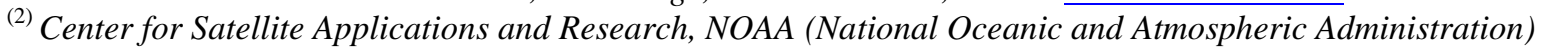 \\ Science Center, 5200 Auth Road Camp Springs, MD 20746 USA, Email: paul.digiacomo@noaa.gov \\ ${ }^{(3)}$ Universidade Federal do Rio Grande, Instituto de Oceanografia, Cx. Postal 474, 96201-900 Rio Grande RS \\ (Brasil), Email: docjhm@furg.br \\ ${ }^{(4)}$ CSIRO (Commonwealth Scientific and Industrial Research Organisation), Marine and Atmospheric Research, \\ GPO Box 1538, Hobart Tasmania 7000 (Australia),Email: john.parslow@csiro.au \\ ${ }^{(5)}$ International Ocean Institute, University of Western Cape, Private Bag X3, Rondebosch, Cape Town, \\ South Africa 7701 (Republic of South Africa),Email: nsweijd@csir.co.za \\ ${ }^{(6)}$ Research Institute for Applied Mechanics, Kyushu University, 6-1 Kasuga-kouen, Kasuga, Fukuoka, \\ 816-8580, Japan, Email: tyanagi@ riam.kyushu-u.ac.jp \\ (7) The Marine Science Institute, University of the Philippines, Diliman, 1101 Quezon City, Philippines, \\ Email: hty@upmsi.ph \\ ${ }^{(8)}$ Laboratoire de Physique des Océans (LPO), UFR (Unité de Formation et de Recherche) Sciences et Techniques, \\ 6, av Le Gorgeu C.S. 93837, 29238 Brest Cedex 3, France,Email: Bruno.Blanke@univ-brest.fr
}

\begin{abstract}
The call for adaptive, ecosystem-based approaches to managing and adapting to the impacts of human activities and global climate change on society has intensified in recent years. Implementing such approaches requires timely and frequent assessments of ecosystem states and reliable predictions of future states based on realistic scenarios of changes in climate and human uses of marine ecosystem goods and services. Provision of the required data is a major motivation for establishing the coastal module of the Global Ocean Observing System (GOOS). Here we review the road map for implementing coastal GOOS, the status of implementation, and the challenges of global implementation. Major challenges include integrated development of the climate and coastal modules of GOOS, sustained capacity building, and the development of "operational marine ecology", the ecological equivalent of ocean forecasting systems for upper ocean physics and maritime weather.
\end{abstract}

\section{INTRODUCTION}

Coastal nations worldwide are experiencing changes in their marine and estuarine ecosystems that jeopardize the safety, health, security and economic wellbeing of over $40 \%$ of the human population [1], [2], [3], [4], [5], [6] and [7]. Since the 1960s, concerns over the causes and consequences of these changes have led to a large and growing body of international agreements aimed at restoring, protecting and sustaining healthy marine ecosystems (Tab. 1). A common theme of these agreements is the need for adaptive, ecosystem-based approaches [8], [9], [10] and [11] to sustainable development [12], [13], [14] and [15] that will maintain the capacity of ecosystems to support goods and services valued by society [16], [17] and [18], approaches that require routine, sustained and interdisciplinary ecological observations and dynamic modeling of marine ecosystems [19] and [20]. We do not have this capability today.

The 1992 UN (United Nations) Conference on Environment and Development (UNCED) and the 2002 World Summit on Sustainable Development (WSSD) both called for integrated observations to routinely and repeatedly assess and predict changing states of oceans and coasts [12] and [13]. Following the WSSD, the Group on Earth Observations (GEO) came together to oversee (1) implementation of a sustained Global Earth Observing System of Systems (GEOSS); (2) capacitybuilding to enable all countries to benefit from and contribute to GEOSS; and (3) full and open exchange of observations recorded from in situ and remote sensing platforms with minimum time delays at minimum cost [21]. Plans addressing each of these objectives are in place for the Global Ocean Observing System (GOOS, the oceans and coasts component of GEOSS) and implementation has begun. But progress has been slow, especially for global implementation of the coastal module of GOOS. 


\begin{tabular}{|c|c|}
\hline Global & $\begin{array}{l}\text { - Ramsar Convention; } \\
\text { - Convention on the Law of the Sea \& the } 2009 \text { UN session on Oceans and Law of the Sea; } \\
\text { - Agreement on the Conservation \& Management of Straddling \& Highly Migratory Fish Stocks, } \\
\text { Convention on Biological Diversity, Convention on International Trade in Endangered Species, } \\
\text { Convention for the Conservation of Migratory Species, Reykjavik Declaration, Code of Conduct for } \\
\text { Responsible Fisheries; } \\
\text { - Framework Convention on Climate Change; } \\
\text { - Global Programme of Action for the Protection of the Marine Environment from Land Based Sources; } \\
\text { - UNCED Agenda 21, Programme of Action for Sustainable Development; } \\
\text { - Implementation Plan of the World Summit on Sustainable Development; } \\
\text { - International Convention for the Prevention of Pollution From Ships }\end{array}$ \\
\hline Africa & $\begin{array}{l}\text { - Convention for Co-operation in the Protection and Development of the Marine and Coastal } \\
\text { Environment of the West and Central African Region (Abidjan Convention); } \\
\text { - The Nairobi Convention for the Protection, Management and Development of the Marine and Coastal } \\
\text { Environment of the Eastern African Region; } \\
\text { - Southern African Development Community Protocol of Fisheries; } \\
\text { - The Benguela Current Commission Interim Agreement (on Marine Ecosystem Based Co-operative } \\
\text { Management) }\end{array}$ \\
\hline Europe & $\begin{array}{l}\text { - European Marine Strategy, Directive \& Framework; } \\
\text { - OSPAR Convention, HELCOM Baltic Sea Action Plan; } \\
\text { - EU Maritime Policy, European Common Fisheries Policy; } \\
\text { - EU Sustainable Development Strategy; } \\
\text { - 'Habitats Directive', Urban Waste Water Directive \& Nitrate Directive. }\end{array}$ \\
\hline Japan & $\begin{array}{l}\text { - Water Quality Conservation Law, Basic Law for Environmental Control, Water Pollution Control Law, } \\
\text { Special Law for the Conservation of the Environment of the Seto Inland Sea; } \\
\text { - Basic Act on Ocean Policy. }\end{array}$ \\
\hline $\begin{array}{l}\text { United } \\
\text { State }\end{array}$ & $\begin{array}{l}\text { - Changing Oceans, Changing world: Ocean Priorities for the Obama Administration and Congress; } \\
\text { - An Ocean Blueprint for the } 21^{\text {st }} \text { Century; } \\
\text { - Clean Water Act, Fishery Conservation \& Management Act, Coastal Zone Management Act, } \\
\text { Endangered Species Act, Oceans and Human Health Act. }\end{array}$ \\
\hline
\end{tabular}

Table 1. A sample (1960 - 2008) of the many global, regional and national ocean policies and related conventions, action plans, agreements and laws requiring the sustained (continuous) provision of data and information on marine ecosystems to achieve their goals and objectives.

\section{MODULES OF THE GLOBAL OCEAN OBSERVING SYSTEM}

GOOS is a global system of systems ( $\mathrm{SoS})$ that systematically acquires and disseminates data and information based on requirements specified by those who use, depend on, manage and study marine and estuarine systems [22]. The SoS is being established through the development of two interdependent modules: (1) a climate (open ocean, basin scale) module and (2) a coastal (marine and estuarine ecosystem scale) module (Tab. 2). The climate module is primarily concerned with more rapid detection and timely predictions of changes in the ocean-climate system (e.g. regional climate patterns and basin-scale oscillations such as the El Nino Southern Oscillation, Pacific Decadal Oscillation and the North Atlantic Oscillation), natural hazards (e.g. tsunami and tropical cyclones), and the effects of natural hazards and global climate change on maritime operations [23] and [24]. The coastal module is primarily concerned with more rapid detection and timely predictions of the impacts of natural hazards, climate change and human activities on public health risks, the health of marine and estuarine ecosystems, and the sustainability of living marine resources in coastal and open ocean waters [25] and [26]. Achieving these societal benefits depends on the routine and continuous provision of data and information on a diverse spectrum of "phenomena of interest" (Tab. 2) through the establishment of a sustained observing and prediction system that efficiently links modeling and measurements via integrated data communication and management (Fig. 1).

Implementing GOOS is a coordinated effort by countries and international organizations to improve our ability to observe and predict changes in ocean states and their impacts by building on, enhancing and expanding existing programs and capabilities (e.g. Box 1). When fully implemented, GOOS will be an integrated, user-driven, multidisciplinary, multi-scale, distributed system of systems. As such, GOOS (1) 


\begin{tabular}{|c|c|c|}
\hline $\begin{array}{l}\text { Societal Benefit } \\
\text { Areas }\end{array}$ & Module & Phenomena of Interest \\
\hline $\begin{array}{l}\text { Marine Weather } \\
\text { \& Climate }\end{array}$ & $\begin{array}{l}\text { Climate \& } \\
\text { Coastal }\end{array}$ & $\begin{array}{l}\text { Variations in water temperature and heat content; Surface fluxes of momentum, heat and fresh } \\
\text { water; Sources \& sinks of heat \& carbon; Sea ice mass \& distribution }\end{array}$ \\
\hline $\begin{array}{l}\text { Maritime } \\
\text { Operations }\end{array}$ & $\begin{array}{l}\text { Climate \& } \\
\text { Coastal }\end{array}$ & $\begin{array}{l}\text { Variations in water level, bathymetry, surface winds, currents \& waves; Sea ice mass \& } \\
\text { distribution; Susceptibility to natural hazards }\end{array}$ \\
\hline Natural Hazards & $\begin{array}{l}\text { Climate \& } \\
\text { Coastal }\end{array}$ & $\begin{array}{l}\text { Coastal flooding \& storm surge; Susceptibility to natural hazards \& coastal erosion; Public } \\
\text { safety \& property loss }\end{array}$ \\
\hline Public Health & Coastal & $\begin{array}{l}\text { Risk of exposure to waterborne pathogens (viruses, bacterial, harmful algae), chemical } \\
\text { contaminants, and biotoxins (contact with water, exposure to aerosols, seafood consumption) }\end{array}$ \\
\hline $\begin{array}{l}\text { Ecosystem } \\
\text { Health }\end{array}$ & Coastal & $\begin{array}{l}\text { Loss of biodiversity; Habitat loss \& modification; Ocean acidification; } \\
\text { Excess nutrient enrichment from anthropogenic sources, accumulations of organic matter, \& } \\
\text { oxygen depletion (cultural eutrophication); Harmful algal events \& invasions of non-native } \\
\text { species; } \\
\text { Chemical contamination of sediments; Diseases in \& mass mortalities of marine organisms }\end{array}$ \\
\hline $\begin{array}{l}\text { Living Marine } \\
\text { Resources }\end{array}$ & Coastal & $\begin{array}{l}\text { Fluctuations in spawning stock size, recruitment \& natural mortality; Changes in areal } \\
\text { extent \& condition of essential habitat; Food availability for harvestable stocks; } \\
\text { Aquaculture production \& water quality }\end{array}$ \\
\hline
\end{tabular}

Table 2. Societal benefit areas of the climate and coastal GOOS modules and associated phenomena of interest [25] are not confined to coastal waters per se (e.g. biodiversity is a global issues). Physical oceanographic and meteorological data are needed for both modules and for all six societal benefit areas.

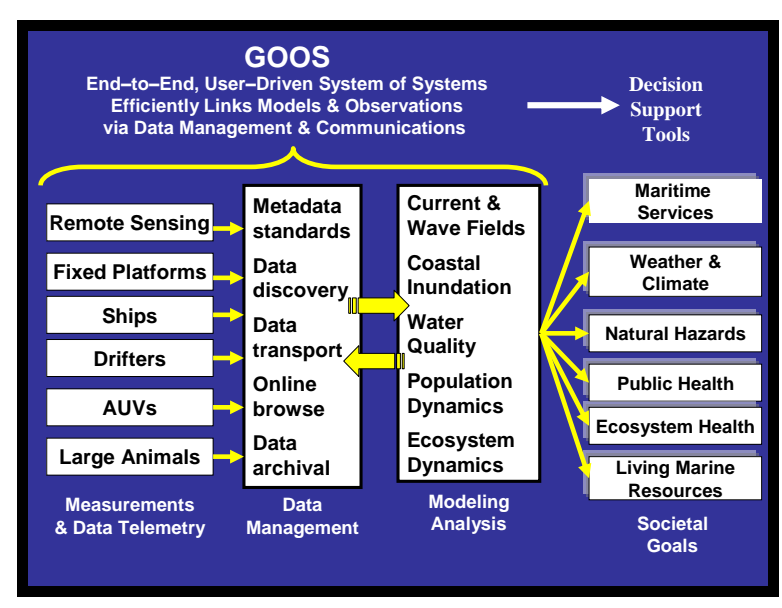

Figure 1. GOOS is an "end-to-end" system that efficiently and continuously links (1) observations and data telemetry to provide the required quality controlled data streams, (2) data management and communication for rapid access to diverse data from many sources, and

(3) data analysis and modeling to provide data, products and services (decision support tools) in forms and at rates specified by decision makers that use, depend on, manage or study marine and estuarine environments and resources.

result of integration); (2) consists of component systems which have their own unique purpose, can be managed separately for that purpose, are able to perform independently of the other components, and do not interfere with the operation of other components; and (3) continually evolves as needs change and new technologies and knowledge become available through scientific research and technical development. In June 2009 , the parties to the $25^{\text {th }}$ Assembly of the Intergovernmental Oceanographic Commission reaffirmed their commitment to sustained implementation of the climate module of GOOS and implementation of the coastal module.

\section{IMPLEMENTATION STATUS OF THE GOOS MODULES}

Substantial progress has been made in the design and implementation of the climate module since UNCED in 1992 [29] and [30]. The Joint WMO-IOC (World Meteorological Organization / International Oceanographic Commission) Technical Commission for Oceanography and Marine Meteorology (JCOMM) has been established to oversee coordinated implementation and the provision of services [31], and the transition of GOOS from planning to the first stages of integration has begun (e.g. the Global Ocean Data Assimilation Experiment, GODAE [32]). Satellite-based remote sensing of sea surface temperature, sea ice, sea surface height, surface waves and currents, and ocean color are operational or rapidly becoming operational [33]. Here the primary challenges are to sustain the temporal continuity of observations, increase their resolution in time and space, and, for ocean color, to increase spectral resolution and improve algorithms for computing pigment concentrations in coastal waters. For in situ observations, nearly $60 \%$ of the initial specification for the climate module has been implemented, and some elements of GOOS are operational globally (e.g. sea surface temperature, waves and currents) [29]. In 


\section{Box 1. Integrating Ecology into GOOS}

The continuous plankton recorder (CPR) of the Sir Alister Hardy Foundation for Ocean Science is an example of a sustained, end-to-end system that has been managed separately, performs independently of GOOS, and is in the process of becoming an integral part of GOOS [27]. The CPR survey has provided the only multidecadal, basin and ecosystem scale in situ data on ecological indicators that document effects of ocean warming and basin scale oscillations on pelagic marine ecosystems and their capacity to support living marine resources. For example, the figure below shows the poleward movement of warm-temperate and temperate zooplankton species between 1958-81 and 2003-05, a clear indicator of a warming ocean [28].
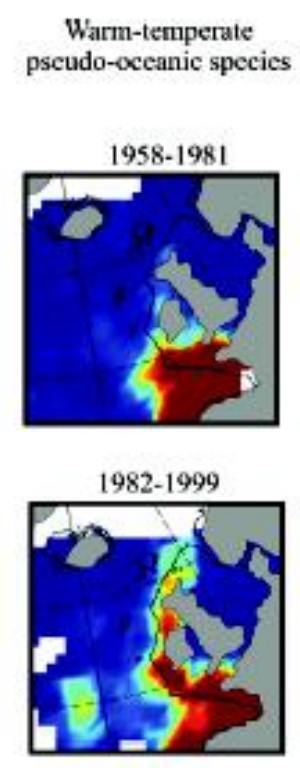

Temperate

pseudo-oceanic species

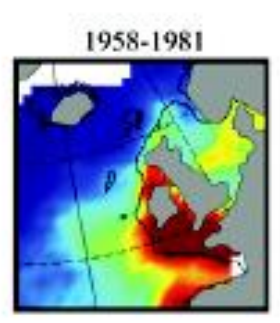

$1982-1999$

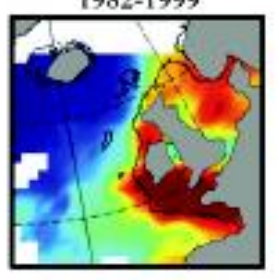

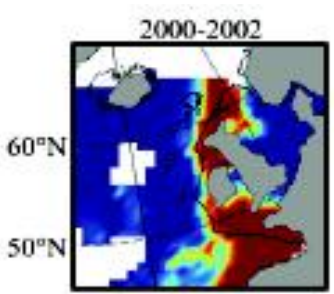
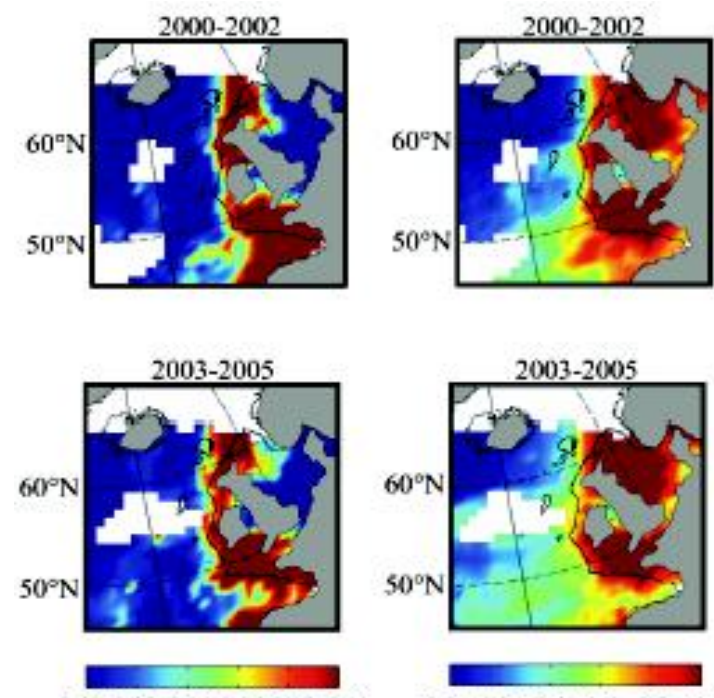

0.000 .020 .040 .060 .080 .10

Mean number of species per CPR sample

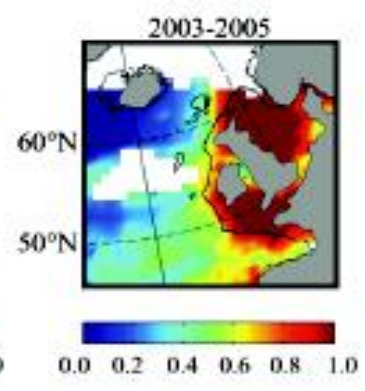

The next steps are to incorporate CPR data streams into models of ecosystem dynamics via GOOS data management and communications and globalize the program to help achieve the goals of both the CPR program and GOOS. This will not be easy and the process underscores some of the many challenges of establishing operational marine ecology as an integral component of GOOS.

addition, services requiring marine meteorological and physical oceanographic data and models are developing rapidly on national and regional scales, e.g. Australia's BlueLink Ocean Forecasting System [34], the Baltic Operational Observing System [35], the Mediterranean Operational Oceanographic Network [36] and the U.S. Physical Oceanographic Real-Time System [37].

The Integrated Design Plan for the Coastal Module calls for establishing regional coastal ocean observing systems (RCOOSs) worldwide and, through this process, the development of a Global Coastal Network (GCN) [25] and [26]. Coordinated development of regional observing systems is needed to create a GCN that (1) measures, manages and analyzes common variables needed by all or most coastal nations and regions; (2) establishes sentinel and reference stations; and (3) implements internationally accepted standards and protocols for measurements, data telemetry, data management and modelling. As recently updated by the Panel for Integrated Coastal Observations (PICO), the provisional common variables include geophysical variables (temperature, salinity, currents, waves, sea level, shoreline position, bathymetry), chemical variables (dissolved inorganic nutrients, dissolved oxygen, pCO2, pH), biological variables (faecal indicators, phytoplankton biomass, benthic biomass), and biophysical variables (bio-optical properties). As recommended in the Integrated Strategic Design Plan for the Coastal Ocean Observations Module, the initial infrastructure of the GCN consist of (1) a global network of coastal laboratories to record and disseminate data on local ecosystem states; (2) the global network of tide gauges (GLOSS); (3) fixed platforms, moorings, drifters and underwater vehicles 
equipped with sensors for measuring the common variables; (4) ships of opportunity and voluntary observing ships (e.g. the Continuous Plankton Recorder And Ferry Box programmes); (5) research vessels and repeat surveys (for sentinel stations and transects); (6) remote sensing from land-based platforms (e.g. high frequency radar for surface currents and waves); and (7) remote sensing from satellites and aircraft (sea surface temperature, height, waves, winds, colour) [25].

Although establishing coastal GOOS is a high priority of the international community, initial specifications for global implementation have yet to be completed. This reflects four important realities:

- The coastal module has a broad and complex mandate with multidisciplinary (geophysical, chemical, and biological) data and information requirements that differ substantially from place to place depending on the relative importance and expression of a broad diversity of phenomena (Tab. 2).

- Most models of ecosystem dynamics and measurements of non-geophysical variables needed to feed them are not operational (Fig. 2).

- Capabilities and capacity building needs vary widely among nations and regions.

- Implementation of the coastal module requires global coordination and collaboration among a large number of coastal nations (wealthy and developing).

The Implementation Strategy for the Coastal Module of GOOS recognizes these challenges and presents over 50 recommendations to address them as step toward formulating observing system specifications [26]. An overarching, cross-cutting recommendations is to establish GOOS Regional Alliances (GRAs) for (1) engaging decision-makers in setting priorities for GOOS development in their respective regions, (2) establishing regional ocean observing systems to meet regional and local information needs of decision makers, and (3) through this process, build an interoperable GCN. The success of this approach will depend, in part, on effective collaboration and coordination with existing regional bodies that have related goals and needs, e.g. IOC Regional Offices [38], Regional Seas Conventions [39], Regional Fishery Bodies [40], and Large Marine Ecosystem programs [41]. (a) Two Related Operational Objectives

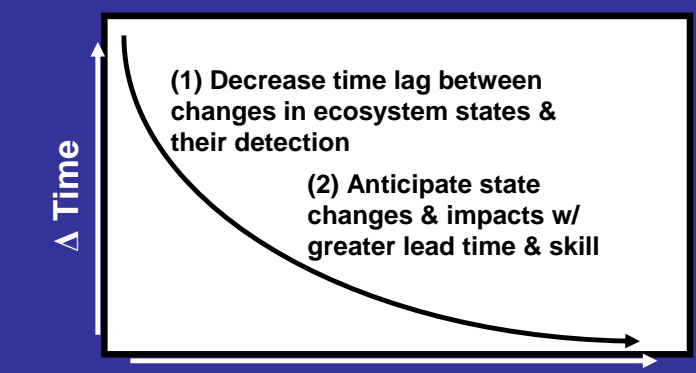

Development of Operational Capabilities

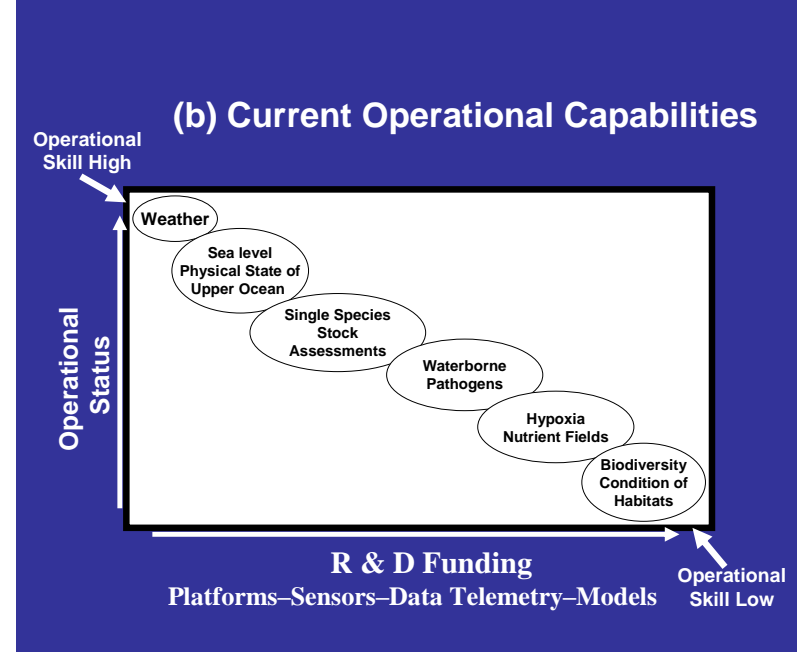

Figure 2. Developing an operational system to support ecosystem-based approaches requires (a) reductions in the time lag between changes in ecosystems and their detection and $(b)$ research to develop technologies and models that can be used in an operational mode.

Over the last 10-15 years, 12 GRAs have been established (Fig. 3a) and regional observing systems for detecting and predicting state changes in the physical environment of the upper ocean are in various stages of development [29 and 30]. Four GOOS Regional Fora have been held $(2002-2008)$ to facilitate coordinated implementation and interoperability, and a GOOS Regional Council has been formed to oversee this process and represent GRAs on the Intergovernmental Committee for GOOS (I-GOOS). However, global implementation of coastal GOOS has been slow and 
uneven geographically. Challenges that must be addressed to take implementation of the coastal module to the next level include the following:

- Engage policy- and decision-makers responsible for environmental protection, resource management, marine conservation, and coastal zone management in the design of GOOS to ensure that the SoS provides data and information that make their work more effective.

- Implement and sustain capacity building programs that enable developing countries and economies in transition, which account for most of the Earth's coastline (Fig. 3b), to contribute to and benefit from

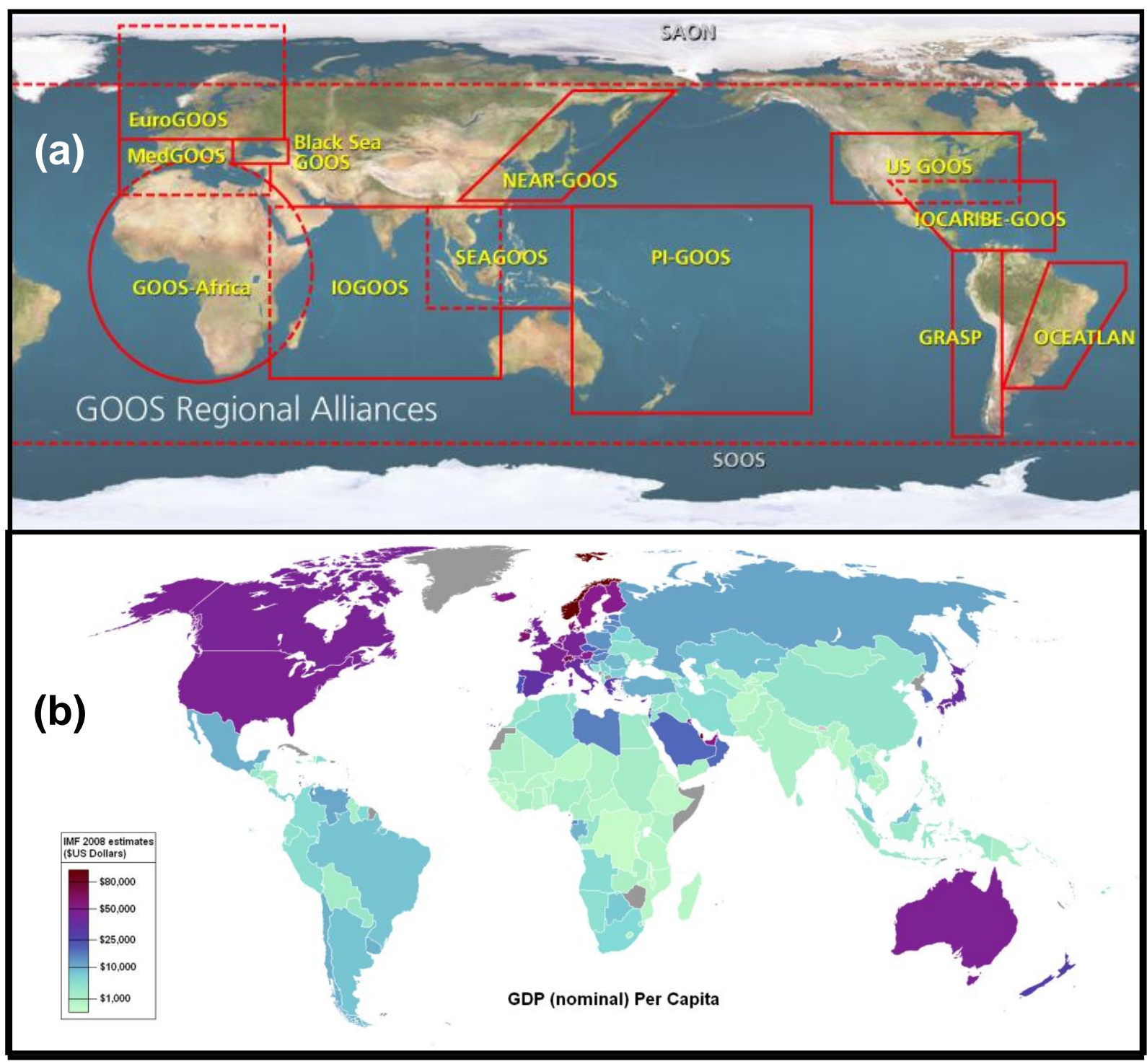

Figure 3. (a) GOOS Regional Alliances (GRAs) have been established to design and implement Regional Coastal Ocean Observing Systems and to build a Global Coastal Network (GCN) of observations, data management and modeling. GRAs in yellow have been recognized by the IOC. Those in grey (SAON (Sustained Arctic Observing Networks) and SOOS (Southern Ocean Observing System)) are in development. (b) Recognizing that countries with low GDP (gross domestic product) per Capita encompass most of the world's coastal ecosystems where GOOS is least developed (if at all), capacity building by the richer nations is critical to global development of coastal GOOS.

GOOS by leaving a legacy of self reliance and self determination;

- Through collaboration and coordination with other regional bodies with related goals [38], [39], [40] and [41], enhance, expand and integrate current assets and capabilities to detect, assess and predict changes in ecological states across the broad spectrum of variability that characterize marine and estuarine ecosystems (e.g. CPR data on plankton communities with physical data on the upper ocean 
from both satellites and in situ observations);

- $\quad$ Tailor the observing system to meet unique regional and national needs for data and information on marine and estuarine ecosystems;

- Overcome social, political and technical barriers to reach international agreements on policies and procedures for timely data exchange among countries on the states of their respective coastal zone;

- Coordinate national and regional development to ensure a global system of systems that is interoperable and meets national needs; and

- Attract funding for all of the above and develop sufficient demand for GOOS data and information by user groups to justify sustained funding.

These challenges can only be addressed in phases and will take time (estimated to be on the order of $10-20$ years).

\section{THE WAY FORWARD}

To facilitate timely and cost-effective establishment of a global coastal ocean observing system, the Panel for Integrated Coastal Observations (PICO, a subcommittee of the GOOS Scientific Steering Committee) was formed in 2008 and tasked with preparing a scientifically sound, realistic, prioritized and phased action plan that can be used to help guide the establishment of a global system of systems for marine and estuarine ecosystems [42].

\subsection{The action plan}

The plan will (1) build on the Implementation Strategy for the Coastal Module [26] and the IGOS Coastal Theme [20]; (2) incorporate recent advances in scientific understanding [3], [4], [5], [6] and [7] and technology [43]; and (3) be guided by input from GOOS Regional Fora and Council [44], the GEO Coastal Zone Community of Practice [45], and invited experts as needed. To facilitate interoperability and ensure proper consideration of boundary conditions (e.g. ocean boundary conditions for coastal marine ecosystems), external forcings (land-based inputs, basin scale oscillations, climate change, etc.) and exchanges across boundaries, planning will be coordinated with the Ocean Observations Panel for Climate (OOPC) [46] and the coastal Panel of the Global Terrestrial Observing System [47]. The plan will include:

- Observing system specifications and an action plan for a prioritized, phased build out of an operational, global system of systems in 5 year increments out to 20 years (with time lines, milestones and cost estimates);
- Priorities for research and regionally organized pilot projects for improving and expanding operational capabilities (proof of concept, demonstration of operational capabilities that address one or more of the societal benefits); and

- Performance metrics for the build out and improving operational capabilities.

Specification of requirements for models and analyses, observations and data telemetry, and data management and communications will be guided by data and information needed to deliver specific decision support tools (products) to those who use, depend on, manage, and study marine and estuarine ecosystems and the goods and services they support. The plan will focus on data and information requirements for adaptive, ecosystem-based approaches to managing, mitigating and adapting to the impacts of human activities, natural hazards and climate change. Formulation and effective implementation of such approaches require (1) scientifically credible, quantitative, robust, costeffective and validated indicators that can be used to assess and anticipate changes in the status of marine ecosystem goods and services; and (2) sustained observations and modeling that enable these indicators to be monitored and analyzed routinely at rates most useful to policy and decision makers responsible for sustainable use of these goods and services. Thus, the process will begin with the identification of indicators for informing assessments of current and future ecosystem states (Fig. 4a). The Driver-Pressure-StateImpact-Response model provides a framework for identifying a set of indicators (Fig. 4b) [48] and [49], sustained monitoring of which will enable early warnings of impacts (driver and pressure indicators), assessments of ecosystem goods and services (state and impact indicators), and evaluations of ocean policies and the efficacy of their implementation (response indicators). "End-to-end" (observations to models) solutions will be specified to provide the data and information required to compute indicators for timely assessments of the following:

- Impacts of sea level rise and coastal flooding events on marine ecosystems and coastal communities;

- Changes in the risk of human exposure to waterborne pathogens;

- Impacts of ocean acidification on the growth and abundance of calcareous organisms;

- Impacts of modification and loss of critical habitats;

- Time-space extent of hypoxic events and their impacts; and

- Changes in the abundance of exploitable living marine resources. 


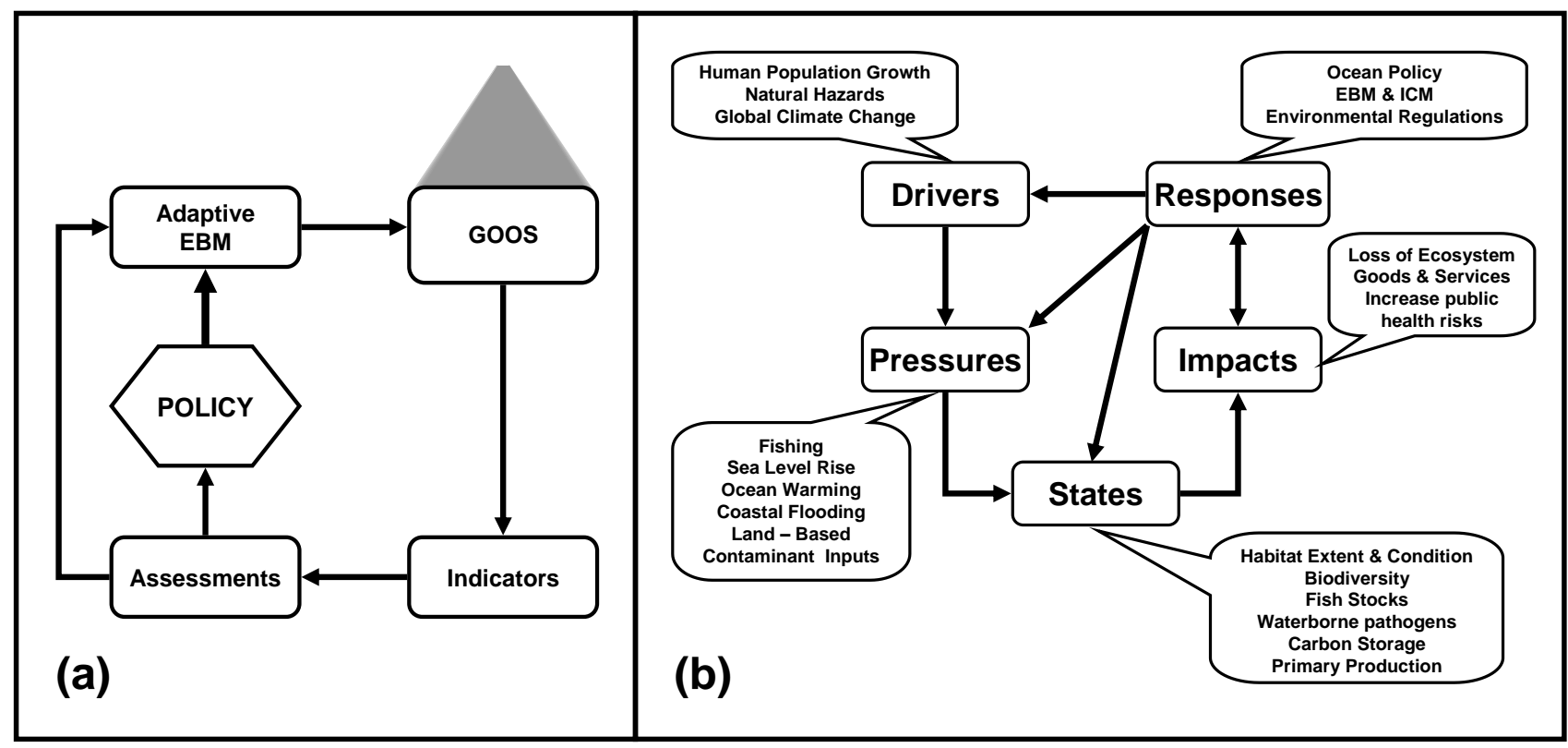

Figure 4. (a) Ecosystems are complex systems characterized by many variable properties and processes that cannot all be monitored in all places at all times. Thus, it is important to identify key ecological indicators that enable assessments needed to guide the evolution of ocean policies and adaptive, ecosystem-based management (EBM) practices for sustainable use of marine ecosystem goods and services. Coastal GOOS must evolve to provide data and information required to compute indicators routinely and continuously. (b) The driver-pressure-state-impact-response (DPSIR) model guides the identification of a set of indicators (with examples for each stage). As a group, the set of indicators will inform integrated ecosystem assessments on local, national, regional and global scales (EBM - ecosystem-based management; ICM - integrated coastal management).

Once end-to-end solutions for each indicator or set of indicators are completed, "cross-cut" analyses to identify common requirements for modeling, observations and data management will be performed. Finally, a prioritized, step-by-step build-out plan with a timetable, milestones and cost estimates will be formulated for global implementation. In the process, operational deficiencies and associated priorities will be identified and used to recommend priorities for pilot and research projects.

\subsection{Improving ecological operational capabilities through pilot projects and ocean research}

Sustained implementation of the coastal module depends on demonstrating the societal benefits of integration in terms of the cost-effective provision of new or improved products and building capacity in developing countries. "Integration" refers to both observing system capabilities for coastal GOOS (e.g. integrating data streams from in situ and remote sensors to generate more accurate, high resolution chlorophyll fields) and to linking the development of the climate and coastal modules. Products include indicators of ecosystem states, impacts of changes in state, and the drivers and pressures that lead to these changes. Sets of indicators are needed for each of the following:
- "Bottom-up" processes such as impacts of anthropogenic nutrient inputs on coastal ecosystems, of ocean acidification on marine plankton populations, and of ocean warming (stratification) on phytoplankton productivity;

- “Top-down" processes such as impacts of declines in the abundance of large marine filter feeders and predators due to overfishing or habitat loss; and

- Habitat-based changes in state such as impacts of ocean acidification on coral reefs, and of habitat loss on living marine resources, biodiversity and susceptibility to natural disasters and climate change.

Physical oceanographic processes fall into the bottomup category through their effects on nutrientphytoplankton-zooplankton fields. Thus, together the Argo [50] and GODAE [32] pilot projects represent a successful end-to-end solution for the provision of GOOS products (e.g. high resolution temperature fields) and a contribution to operational marine ecology. Harmful algal bloom forecasting systems [51] and the CPR programme [27] are examples of operational bottom-up systems. Examples of operational habitatbased observing systems include the Global Coral Reef 
Monitoring Network (GCRMN) [52] and the Global Sea Grass Monitoring Network (SeaGrass Net). [53] All of these are building blocks of GOOS, but they have yet to be incorporated into an integrated system of systems.

Pilot projects, advances in ocean science, and new technologies are critical to developing operational capabilities for ecosystem-based approaches. ChloroGIN [54] and the Ocean Tracking Network [55] are, respectively, examples of bottom-up and top-down GOOS pilot projects. Both are represented here at OceanObs'09. Integration of these data streams with data from the CPR programme and Harmful Algal Bloom Forecasting Systems would provide a powerful means of assessing potential impacts of climate change, natural hazards and human activities on coastal ecosystem goods and services (e.g. nutrient cycling, productivity, and fisheries) and public health (e.g. risk of exposure to toxins from harmful algal blooms).

In situ technologies that are currently transitioning from research to an operational mode include sensor for measuring dissolved oxygen, $\mathrm{pCO}_{2}$ and $\mathrm{pH}$ [43]. Promising new in situ technologies that are currently in a research mode and have potential for operational, near real-time detection of bottom-up changes in state include bio-optical sensors (phytoplankton biomass, productivity, size structure and florlistic composition), flow cytometers (particle size spectra and floristic composition), optical plankton recorders (zooplankton abundance), and species specific molecular probes (abundance of waterborne pathogens and phytoplankton species). Some of these emerging technologies are being tested in pilot projects and are represented at OceanObs'09 including the following [56]:

- Bio-optical Profiling Floats as New Observational Tools for Biogeochemical and Ecosystem Studies: Potential Synergies with Ocean Colour Remote Sensing,

- Coupling Bio-Optical Measurements of Ocean Parameter Made From Underwater Autonomous Gliders and Ocean Color Satellites,

- In Situ Nutrient Sensors for Ocean Observing Systems,

- Sensors and Systems for Observations of Marine CO2 System Variables,

- Ocean Acidification Observational Network,

- Adding Oxygen to Argo: An Opportunity to Develop a Global in-situ Observatory for Ocean Productivity and Biogeochemistry in a Changing Climate,

- Optical Plankton Imaging Systems for Ocean Observations,
- Multidisciplinary Observation of the Surface Ocean and Lower Atmosphere from Ship Transects, and

- Ecogenomic Sensors.

Promising technologies for top-down detection include acoustic fish surveys, coded acoustic transmitters that can be implanted in fish to track their movements using cross-shelf hydrophone arrays, and electronic tags and sensors that can be implemented in tunas, sharks, turtles, seals, whales and seabirds to track their movements (location and depth) and measure the temperature and salinity of their environment as they move. Some of these technologies are also represented at OceanObs'09 including [56]

- TOPP as a Marine Life Observatory: Using Electronic Tags to Monitor the Movements, Behavior and Habitats of Marine Vertebrates,

- Biologging in the Global Ocean Observing System,

- A Global Ocean Acoustic Observing Network,

- Designing and Deploying a Global Ocean Midtrophic Automatic Acoustic Sampler (MAAS), and

- $\quad$ The Ocean Tracking Network.

Development of these technologies underscores the importance of facilitating synergy between research and the growth of operational capabilities, especially for ecosystem based approaches. Thus, the success of international research programs such as LOICZ (LandOcean Interactions in the Coastal Zone), GEOHAB (Global Ecology and Oceanography of Harmful Algal Blooms), GLOBEC (Global Ocean Ecosystem Dynamics), and IMBER (Integrated Marine Biogeochemistry and Ecosystem Research) is critical to the development of operational ecological capabilities in GOOS. Establishing working relationships with these and other relevant research programs is a priority for PICO.

\subsection{Integrating the climate and coastal modules}

To date, the climate and coastal modules of GOOS have been developing more or less independently of each other. This needs to change soon for at least two reasons. First, variability and changes in the oceanclimate system on global to basin scales impact coastal ecosystems and their capacity to support goods and services. [57], [58], [59] and [60] Thus, the observing system must not only provide data and information needed to determine spatial boundary conditions, it must capture the propagation of variability and change from global and ocean basin scales to the local scale of ecosystems [61], [62] and [63] Second, much of the justification for investing in the climate module is based 


\section{Box 2. The Insurance Industry and Coastal Inundation From The Geneva Reports, 2009, No. 2, 138 pp. \\ www.genevaassociation.org}

Some of the first and most severe impacts of climate change will come through greater storm surges caused by a combination of higher sea levels and stronger storms in some regions. In the absence of storm surge, a $20-80 \mathrm{~cm}$ rise in mean sea level will place $7-300$ million additional people at risk of being flooded each year [65]. Increases in storm

surge will increase these numbers substantially. The Organization for Economic Cooperation and Development (OECD) estimates that, in the absence of adaptation, the population in 136 major port cities exposed to storm surges could increase from 40 million in 2005 to $\sim 150$ million in the 2070 s with exposed assets rising from US $\$ 3,000$ billion to US $\$ 35,000$ billion [66]. As a proportion of GDP, economic losses from flooding are much higher for developing countries that for developed countries [67]. Financial losses from weather events are currently doubling every 12 years at an annual rate of $6 \%[68]$.

To adapt to greater storm surges, one option for at-risk regions is to invest in hard defenses such as flood barriers or in

the maintenance and restoration of natural ecological buffers such as tidal wetlands, seagrass beds, kelp beds, coral reefs, and barrier islands that retain floodwater, dampen storm surges and/or prevent coastal erosion. Building codes can be strengthened by incorporating flood and storm proofing measures (e.g. property elevation, engineered foundations, reinforced cladding). Drainage systems can be improved or installed to handle larger volumes of water. Managed retreat from the shoreline can be implemented in regions deemed to be too costly to protect. Critically, early warning observing and prediction systems and sound strategies for adaptation (from evacuation to land-use practices) are needed to reduce exposure risks. This is especially important in the developing world here human exposure is often substantial, vulnerabilities are high, and investment available for other options is low.

The use of risk-based pricing for insurance can stimulate adaptation that reduces risk. Where observations are of sufficient granularity, insurers can often differentiate between risks. The presence of risk reduction methods can be indicative of lower claims, which justifies lower premiums. Conversely, a regulatory regime that does not allow risk-

based pricing can lead to responses by the public and business that exacerbate coastal flooding risks. Insurers that provide liability insurance can also motivate professionals to give climate-risk advice to their clients recognizing that those who do not are open to legal challenges that may lead to professional indemnity or errors and omissions claims.

assessments (more rapid detection and timely, reliable predictions) of when and how large scale changes in the ocean-climate system will be expressed in terms of changes in the capacity of marine and estuarine ecosystems to provide goods and services, i.e., when and how large scale changes will impact coastal ecosystems where the potential demand for GOOS data and information is greatest.

\subsection{An integrated climate-coastal observing system: A realistic first step}

Phased implementation of the global coastal network requires prioritization of the proposed pilot projects. Six criteria were used to do this:

- Products and/or services are needed worldwide

- Data integration must lead to more accurate and timely assessments of ecosystem states and predictions of changes in state that have major socio-economic consequences on a global scale.

- Such assessments and predictions must inform decision makers working in two or more of the societal benefit areas (Tab. 2).
- Data integration resulting in new and improved products and services must occur sooner than later (e.g. 2 years).

- Data streams produced by existing monitoring assets must be sustainable, reliable, \& quality controlled.

- The project requires collaboration between the OOPC and PICO and between developers of the climate and coastal modules of GOOS to design, implement, and complete.

Improving the reliability of model-based predictions of (1) climate-driven sea level rise and hazard-driven (tropical cyclones, tsunami, etc.) coastal inundation and (2) the impacts of sea level rise and coastal inundation on public health risks, coastal marine ecosystems, and their goods and services meet these criteria and should be a high priority for the initial phases of coastal GOOS implementation (e.g. Box 2). Given the emphasis of the ocean-climate module of GOOS on the former, our focus here is on detecting and predicting the impacts of sea level rise and coastal inundation. 
Rising sea levels will have significant impacts on coastal populations and ecosystems worldwide. Climate-driven sea level rise will exacerbate the impacts of tropical cyclones, extra-tropical storms (baroclinic, mid-latitude and winter storms), nor'easters and tsunami. Flooding events will become more frequent and severe; tidal wetlands, sand dunes, river deltas and other low lying land forms will be gradually inundated and eroded; coral reefs will receive less light exacerbating the effects of ocean warming and acidification (e.g. Box 3); salinity will increase in estuaries; and aquifers will be contaminated with salt. Subsequent runoff events will increase risks of public exposure to waterborne pathogens and chemical contaminants, degrade the health of coastal marine and estuarine ecosystems, and impair their ability to support goods and services, including the sustainability of living marine resources.

Since the human and environmental disaster of the December 2004 Indian Ocean tsunami, improving forecasts of the timing, location and magnitude (timespace extent) of coastal inundation events (hazard intensity and probability) has become an international priority. Unfortunately, our ability to provide reliable, long-term, quantitative predictions of changes in ecosystem states on spatial scales needed for ecosystembased coastal planning and public health management is limited at best. The problem is exacerbated by current limitations and the reliability of real-time predictions of local mean sea level and long-term predictions of absolute sea level rise on local-regional space scales.

\section{Box 3. Loss of Coral Reef Habitats: An Example of Ecosystem Scale Impacts of Global Climate Change}

Coral reef ecosystems are among the most biologically diverse, economically important ecosystems on earth. They support $\sim 25 \%$ of marine species and provide ecosystem goods and services valued by society including fisheries, coastal protection, building materials, biochemical compounds and tourism [18]. A recent estimate valued the annual net economic benefits of the world's coral reefs at $\$ 30$ billion [68]. Yet coral reefs are deteriorating at an alarming rate. Nearly $20 \%$ of the world's coral reefs have been lost over the last two decades; $15 \%$ are seriously threatened with loss within the next 10-20 years; and 20\% are under threat of loss in 20-40 years [53]. The primary causes of these changes in the spatial extent and health of coral reefs are local, anthropogenic pressures (fishing and increases in sediment and nutrient loading from land-based sources) and global pressures of climate change (warming of the upper ocean, sea level rise, and ocean acidification) [69]. Reference [69] simulated the ecological implications of a $21 \%$ decline in the rate of coral reef growth (measured rate of decline for the Great Barrier Reef Porites). Trajectories for three possible scenarios were run. (A) If $\left[\mathrm{CO}_{2}\right]_{\mathrm{atm}}$ stabilizes at the current level of $380 \mathrm{ppm}$, coral reefs will continue to change but will remain dominated by carbonate accreting corals. Local pressures become the primary determinants the health of coral reefs. (B) Given the current rate at which $\left[\mathrm{CO}_{2}\right]_{\mathrm{atm}}$ is increasing, reef erosion will exceed calcification when $\left[\mathrm{CO}_{2}\right]_{\mathrm{atm}}$ reaches 450-500 ppm. Under this scenario, the growth and biodiversity of coral reefs decline leading to reductions in the extent and diversity of coral reef ecosystems and associated declines in animal populations (fish and invertebrates). (C) Should $\left[\mathrm{CO}_{2}\right]_{\mathrm{atm}}$ increase $>500 \mathrm{ppm}$, coral reefs will become rapidly eroding rubble banks resulting in the loss of coral-dependent fauna ( $50 \%$ or more), dominance of macroalgae, and frequent phytoplankton blooms.
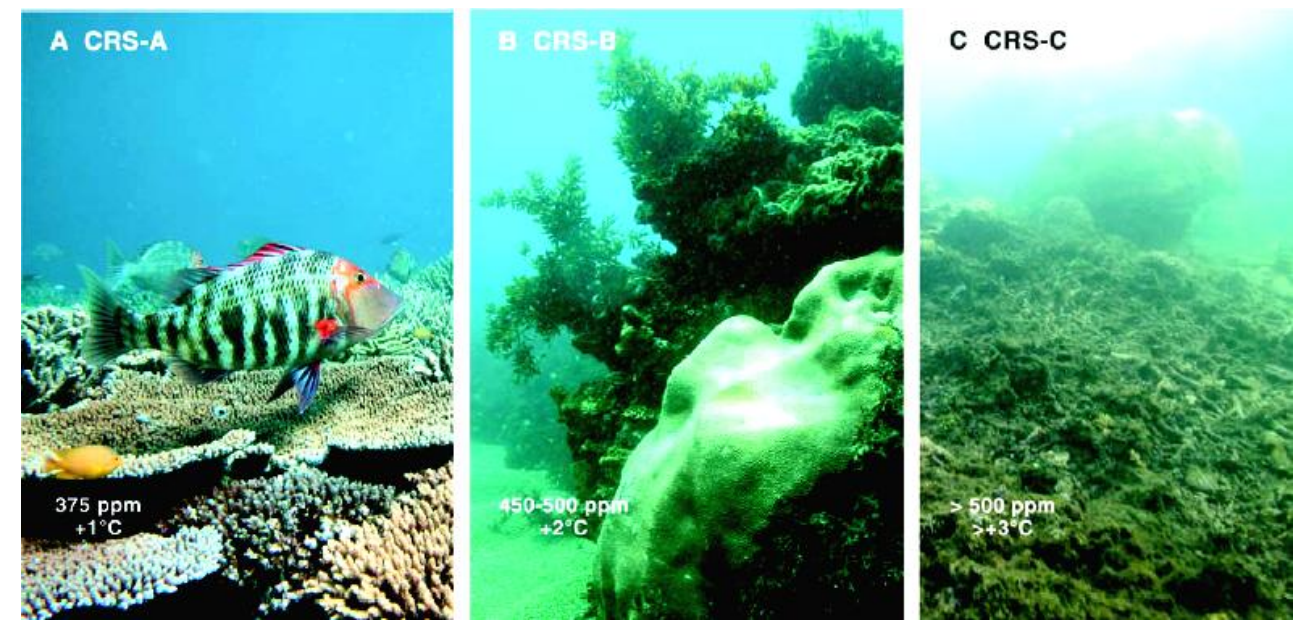
With this in consideration and building on the important effort to improve forecasts of inundation events, the recommended end-to-end solution for coastal inundation focuses on data and information requirements for managing vulnerability.

Managing and mitigating the impacts of coastal inundation require high resolution, digital, geospatial nowcasts and $5-10$ year forecasts of vulnerability to coastal inundation that are updated at $1-10$ year intervals depending on coastal geomorphology anthropogenic modifications of coastal habitats. Such maps must be grounded in observations and capture the effects of changes in shoreline position, near shore bathymetry and topography (e.g. from $50 \mathrm{~m}$ below to $100 \mathrm{~m}$ above local mean sea level relative to a single internationally adopted vertical datum), the extent and condition of near shore habitat buffers (e.g. coral reefs, seagrass beds, intertidal wetlands, dunes), human population density, and spatial extent of impermeable surfaces and hardened shoreline. An end-to-end solution for the provision of vulnerability maps as an integrated product is given in Tab. 3 .

\begin{tabular}{|c|c|}
\hline Indicator & Digital, high resolution, geospatial maps of vulnerability to inundation \\
\hline End - Users & $\begin{array}{l}\text { Government: Policy makers and managers responsible for Flood Plain and Emergency } \\
\text { Management, Land-Use, Coastal Zone and Resource Management; Environmental Protection; } \\
\text { Transportation and Public Works; } \\
\text { Private Sector: Developers, Construction and Real Estate; Insurance and Re-insurance, Non- } \\
\text { Governmental Organizations; } \\
\text { The public }\end{array}$ \\
\hline Data Providers & $\begin{array}{l}\text { Operational government agencies (e.g. for the U.S., NOAA, ACE, USGS), private consulting } \\
\text { firms, and scientists }\end{array}$ \\
\hline $\begin{array}{l}\text { Required Observations } \\
\text { (remote and in situ sensing) }\end{array}$ & $\begin{array}{l}\text { Geospatial boundaries of areas susceptible to flooding } \\
\text { Within each area, continuous measurements of } \\
\text { - Sea level along the land sea-interface at representative locations } \\
\text { - River flows } \\
\text { Within each area, repeat at } 5 \text { year intervals and post flooding events: } \\
\text { - Digital, high resolution, geospatial mapping of bathymetry-topography across the land sea } \\
\text { interface in these areas } \\
\text { - Spatial extent and condition of near shore habitats (coral reefs, seagrass beds, mangrove } \\
\text { - forests, tidal marshes, beaches and dunes, barrier islands) } \\
\text { - Near shore land uses (hardened shoreline, impervious surfaces, farm lands) and land cover } \\
\text { (forests, grasslands) }\end{array}$ \\
\hline Model Requirements & $\begin{array}{l}\text { Algorithms to compute levels susceptibility using the required observations } \\
\text { Geographic Information Systems to map levels of susceptibility }\end{array}$ \\
\hline Operational Status & $\begin{array}{l}\text { The technology exists to make the required observations and maps (tide gauges and airborne } \\
\text { LIDAR and photography) } \\
\text { Algorithms for computing levels of susceptibility are in development } \\
\text { Model for generating geospatial maps of levels of susceptibility are in development }\end{array}$ \\
\hline $\begin{array}{l}\text { Priority Research and Pilot } \\
\text { Projects }\end{array}$ & $\begin{array}{l}\text { Determine optimum locations for tide gauges for accurate estimates of sea level continuously along } \\
\text { the shoreline } \\
\text { Develop algorithms and geospatial models to provide digital, high resolution maps of susceptibility } \\
\text { to flooding } \\
\text { Validate maps } \\
\text { Build capacity in high risk, developing countries }\end{array}$ \\
\hline
\end{tabular}

Table 3. Example of an end-to-end solution for the provision of indicators to end-users responsible for coastal zone management and for managing and mitigating the impacts of coastal inundation (modified from [70]). Regions to be targeted include major river deltas, low lying coastal land forms, and small island development states.

Maps of vulnerability will not only be important for land-use planning, habitat restoration, and insurance purposes, they will provide a framework for assessing changes in resiliency to and impacts of coastal inundation and sea level rise on coastal ecosystem goods and services. Both of the latter require preplanned, adaptive sampling scenarios that can be implemented immediately following inundation runoff events to document and assess ecological impacts, the ability of impacted socio-economic and ecological systems to recover, and the time-course of recovery or change. This includes impact assessments on coastal infrastructure, distributions of waterborne pathogens and chemical contaminants, coastal habitats, and living marine resources. 
The efficacy of recommendations given above depends on collaboration with the OOPC and implementers of the climate module and natural hazard warning systems to ensure the following:

- Continuity in satellite radar altimetry missions (e.g. Jason 3 will be launched on schedule in 2013);

- Completion of a sustained Global Geodetic Observing System (GGOS);

- Expansion of the Global Sea Level Observing System (GLOSS) with improvements (optimize the distribution and number to gauges based on local, regional and global data requirements; equip more gauges with GIS (Geographic Information System) and real-time data telemetry as required to improve predictions of local mean sea level and absolute sea level rise);

- Development of numerical model predictions of local mean sea level (relative to a land-based benchmark) that are operational (validated, routine and reliable with data assimilation) on event to seasonal time scales; and

- Operational development of numerical predictions of absolute (eustatic) sea level rise for predictions of annual to decadal trends.

\section{CONCLUSIONS}

The need for adaptive, ecosystem-based approaches to managing, mitigating and adapting to the impacts of human activities and climate change is greatest in the coastal zone where people and ecosystem goods and services valued by society are most concentrated. Effective adaptation and management depend on rapid access to diverse data on marine and estuarine ecosystems from many sources. Thus, high priority must be given to the establishment of a system of data management and communications that minimizes the time required to acquire, process and analyze data of known quality in both real-time and delayed modes as needed. Implementation of the climate module of GOOS must be sustained and implementation of the coastal module on a global scale must be initiated, adequately resourced and coordinated with the developing climate module. Major challenges to be addressed include sustained development of GRAs in the developing world; capacity building in developing countries that leaves a legacy of self-determination and self-sufficiency; and more effective collaboration and coordination among GRAs, LMEs (Large Marine Ecosystems) and regional seas conventions.

Pilot projects are needed that promote partnerships between developed and developing countries to address user-defined needs in developing countries, build capacity, facilitate coordinated development of the climate and coastal modules of GOOS, and enable sustained development of GRAs. To these ends, high priority should be given to funding regionally organized pilot projects that engage data providers and decision makers to improve the skill of model predictions of the following:

- Impacts of sea level rise and coastal flooding events on marine ecosystems and coastal communities;

- Changes in the risk of human exposure to waterborne pathogens;

- Impacts of ocean acidification on the growth and abundance of calcareous organisms;

- Impacts of modification and loss of critical habitats;

- Time-space extent of hypoxic events and their impacts; and

- Changes in the abundance of exploitable living marine resources.

A prioritized and phased build-out plan for coastal GOOS should be completed within 2 years that recommend end-to-end solutions for each of these proposed projects.

Bodies needed to oversee coordinated implementation of the climate (JCOMM) and coastal (GRAs and the GOOS Regional Council) modules are in place or in various stages of development, and the technologies required for operational marine ecology are emerging. High priority immediate needs are as follows:

- More effective collaboration between JCOMM and the GRA enterprise (via the GOOS Regional Council) to facilitate coordinated development of the climate and coastal modules of GOOS and increased user demand for GOOS data and information;

- International agreement on priorities for global implementation of coastal GOOS and collaboration to ensure effective use of limited resources (rather than competition for them);

- Commitments by rich nations to fund the development of coastal GOOS on a global scale through sustained capacity building in the developing world; and International agreements to ensure rapid, timely and open access to monitoring data from national EEZs (Exclusive Economic Zone) globally.

Achieving these objectives will require clearer definition of the roles and responsibilities of intergovernmental bodies (IOC, I-GOOS, WMO, JCOMM, GSSC (GOOS Scientific Steering Committee)) and international bodies (GRAs, Group on Earth Observations [GEO] , Partnership for 
Observations of the Global Ocean [POGO]) and stronger "user pull" from coastal nations worldwide to justify sustained funding of operational oceanography and marine ecology. The latter depends in part on coordinated development of the climate and coastal modules of GOOS and the establishment of GRAs that engage participating nations and user groups in designing, implementing, and improving GOOS and the linkage between the climate and coastal GOOS modules.

\section{REFERENCES}

1. Jackson, J.B.C., Kirby, M.X., Berger, W.H., Bjorndal, K.A., Botsford, L.W., Bourque, B.J., Bradbury, R.H. Cooke, R., Erlandson, J., Estes, J.A., Hughes, T.P., Kidwell, S., Lange, C.B., Lenihan, H.S., Pandolfi, J.M., Peterson, C.H., Steneck, R.S., Tegner, M.J. \& Warner, R.R. (2001). Historical overfishing and the recent collapse of coastal ecosystems. Science 293, 629-643

2. Small, C. \& Cohen, J.E. (2004). Continental physiography, climate, and the global distribution of human population. Current Anthropology 45 (2), 269-279.

3. Pachauri, R.K. \& Reisinger, A. (Eds.) (2007). Climate Change 2007: Synthesis Report, Contribution of Working Groups I, II and III to the Fourth Assessment Report of the Intergovernmental Panel on Climate Change, IPCC, Geneva, Switzerland. pp 104.

4. Hoegh-Gulberg, O., Mumby, P.J., Hooten, A.J., Steneck, R.S., Greenfield, P., Gomez, E., Harvell, C.D., Sale, P.F., Edwards, A.J., Caldeira, K., Knowlton, N., Eakin, C.M., Iglesias-Prieto, R., Muthiga, N., Bradbury, R.H., Dubi, A. \& Hatziolos, M.E. (2007). Coral Reefs Under Rapid Climate Change and Ocean Acidification. Science 318, 1737-1742.

5. Diaz, R.J. \& Rosenberg, R. (2008). Spreading dead zones and consequences for marine ecosystems. Science $\mathbf{3 2 1}$ (5891), 926-929.

6. UNEP (2008). UNEP Year Book, An Overview of Our Changing Environment 2008, UNEP, Paris, France, pp 51 .

7. Halpern, B.S., Walbridge, S., Selkoe, K.A., Kappel, C.V., Micheli, F., D'Agrosa, C., Bruno, J.F., Casey, K.S., Ebert, C., Fox, H.E., Fujita, R., Heinemann, D., Lenihan, H.S., Madin, E.M.P., Perry, M.T., Selig, E.R., Spalding, M., Steneck, R. \& Watson, R. (2008). A global map of human impact on marine ecosystem. Science, $\mathbf{3 1 9}$ (5865), 948-952.

8. Sherman, K., Alexander, L.M. \& Gold, B.D. (eds.) (1993) Large Marine Ecosystems: Stress, Mitigation, and Sustainability, AAAS Press, Washington, D.C., pp. 376.

9. Turrell, W.R. (2004). The Policy Basis of the "Ecosystem Approach" to Fisheries Management, EuroGOOS Publication No. 21, EuroGOOS Office, SMHI, 60176 Norrköping, Sweden, pp. 28.
10. Garcia, S.M. \& Cochrane, K.L. (2005). Ecosystem approach to fisheries: a review of implementation guidelines. ICES J. Mar. Res. 62, 311-318.

11. Murawski, S., Cyr, N., Davidson, M., Hart, Z., Balgos, M., Wowk, K., \& Cicin-Sain, B. (2008). Policy Brief: Ecosystem-based management and integrated coastal and ocean management and indicators for progress. 4th Global Conference on Oceans, Coasts, and Islands.

12. UN. 1992. United Nations Conference on Environment and Development, Agenda 21(http://habitat.igc.org/agenda21/)

13. United Nations (2002). Global Challenge, Global Opportunity: Trends in Sustainable Development, pp 21 (http://www.un.org/jsummit/html/documents/summit_do cs/criticaltrends_1408.pdf).

14. Dasgupta, P. (2007). The idea of sustainable development, Sustainability Science 2(1), 5-11.

15. Hasna, A. M. (2007). Dimensions of sustainability, $J$. Engineering for Sustainable Development: Energy, Environment, and Health 2 (1), 47-57.

16. Costanza, R., d'Arge, R., de Groot, R., Farberk, S., Grasso, M., Hannon, B., Limburg, K., Naeem, S., O’Neill, R.V., Paruelo, J., Raskin, R.G., Suttonk, P. \& van den Belt, M. (1997). The value of the world's ecosystem services and natural capital. Nature 387, 253-260.

17. Worm, B., Barbier, E.B., Beaumont, N., Duffy, J.E., Folke, C., Halpern, B.S., Jackson, J.B.C., Lotze, H.K., Micheli, F., Palumbi, S.R., Sala, E., Selkoe, K.A., Stachowicz, J.J. \& Watson, R. (2006). Impacts of biodiversity loss on ocean ecosystem services. Science 314 (5800), 787-790

18. Moberg, F. \& Folke, C. (1999). Ecological goods and services of coral reef ecosystems. Ecol. Econ. 29, 215233.

19. Malone, T.C., Knap, T. \& Fogarty, M. (2004). Overview of science requirements. In The Sea, The Global Ocean Multiscale Interdisciplinary Processes, v. 13. Robinson, A.R. and K Brink (eds), Harvard University Press, Boston, pp. 1024

20. UNESCO 2006. A Coastal Theme for the IGOS Partnership for Monitoring our Environment from Space and Earth. IOC Information Document No. 1220, pp. 49 (www.igospartners.org/Coastal.htm).

21. The Global Earth Observing System of Systems, http://www.earthobservationsummit.gov/declaration.htm 1; http://www.epa.gov/geoss/; http://www.noaa.gov/eos.html.

22. UNESCO (1998). The Global Ocean Observing System Prospectus 1998. GOOS Report No. 42, pp. 168.

23. UNESCO.1999. Global Physical Observations for GOOS/GCOS: An Action Plan for Existing Bodies and Mechanisms. GOOS Report No. 66. 
24. Koblinsky, C.J. and N. R. Smith (eds.). 2001. Observing the Oceans in the 21st Century: A Strategy for Global Ocean Observations, GODAE Project Office, Bureau of Meteorology, Australia, pp 604.

25. UNESCO (2003). The Integrated Strategic Design Plan for the Coastal Ocean Observations Module of the Global Ocean Observing System. GOOS Report No. 125, pp 190.

26. UNESCO (2005). An Implementation Strategy for the Coastal Module of the Global Ocean Observing System. GOOS Report No. 148, pp 141.

27. Reid, P. \& Co-Authors (2010). "A Global Continuous Plankton Recorder Programme" in these proceedings (Vol. 2), doi:10.5270/OceanObs09.cwp.73.

28. Edwards, M., Beaugrand, G., John, A.W.G., Johns, D.G., Licandro, P. \& McQatters-Gollop, A. (2009). Ecological Status Report: results from the CPR survey 2007/2008. SAHFOS Technical Report, 6, 1-12. Plymouth, U.K. ISSN 1744-0750).

29. UNESCO. 2009. Progress Report on the Implementation of the Global Observing system for Climate in Support of the UNFCCC 2004-2008. GOOS Report No. 173, pp. 98 (http://gcos.wmo.int).

30. GOSIC (2009) Overview of the growth of GOOS observation programs (http://www.gosic.org/goos/GOOS-observationalprograms.htm).

31. The Joint WMO-IOC Technical Commission for Oceanography and Marine Meteorology (http://www.jcomm.info/)

32. Bell, M. \& Le Traon, P-Y. (editors) (2009) Special Issue on the Revolution of Global Ocean Forecasting GODAE: 10 Years of Achievement, Oceanography 22 (3), 14-225

33. Committee on Earth Observation Satellites (2007). The CEOS Implementation Plan for Space-Based Observations For GEOSS, Version 0.2.6, pp. 195 (www.ceos.org/images/PDFs/ceos_ipdraft_nov2007.pdf)

34. BLUElink > Ocean forecasting Australia (http://www.bom.gov.au/bluelink/).

35. Baltic Operational Oceanographic System (www.boDos.org/)

36. Mediterranean Operational Oceanographic Network (www.moon-oceanforecasting.eu/).

37. U.S. Physical Oceanographic Real-Time System (http://tidesandcurrents.noaa.gov/ports.html)

38. IOC Regional Offices (http://www.iocgoos.org/index.php?option=com content $\&$ view=article \&id=159\&Itemid=89\&lang=en)

39. Regional Seas Conventions (www.unep.org/regionalseas/

40. Regional Fishery Bodies (www.fao.org/fishery/rfb/search/en)

41. Large Marine Ecosystem Programs (www.lme.noaa.gov/)
42. IOC Panel for Integrated Coastal Observations (http://www.iocgoos.org/index.php?option=com oe\&task=viewDocume $\underline{\text { ntRecord\&docID }=116 \text { ) }}$

43. The Alliance for Coastal Technologies (ACT) (http://www.act-us.info/).

44. GOOS Regional Fora and Regional Council (www.iocgoos.org )

45. GEO CZCP (http://www.czcp.org/)

46. Ocean Observations Panel for Climate (OOPC) (http://ioc3.unesco.org/oopc/)

47. Coastal Global Terrestrial Observing System (GTOS) (http://www.fao.org/gtos/c-gtos.html).

48. Bowen, R.E. \& Riley, C. (2003). Socio-economic indicators and integrated coastal management. Ocean Coastal Management, 46, 299-312.

49. Niemeijer, D. \& de Groot, R.S. (2008). A conceptual framework for selecting environmental indicator sets. Ecological Indicators, 8(1), 14-25.

50. Roemmich, D. \& the Argo Steering Team (2009). Argo: The challenge of continuing 10 years of progress. Oceanography, 22 (3), 46-55.

51. Malone, T.C. (2008). Ecosystem dynamics, harmful algal blooms and operational oceanography, In Real-time Coastal Observing Systems for Marine Ecosystem Dynamics and Harmful Algal Blooms (Babin, M., Roesler, C.S. \& Cullen, J.J., Eds.), Oceanographic Methodology Series, UNESCO Publishing, Paris, France, 527-559.

52. Wilkinson, C. (ed.) (2008). Status of Coral Reefs of the World: 2008, Global Coral Reef Monitoring Network and Reef and Rainforest Research Center, Townsville, Australia, pp 296

53. Short, F.T., Coles, R.G., Koch, E. \& Fortes, M. (2004). Western Pacific Seagrass Monitoring Program: SeagrassNet Year 3 Report, pp. 31 (www.seagrassnet.org/).

54. Sathyendranath, S. \& Co-Authors (2010). "ChloroGIN: Use of Satellite and In Situ Data in Support of Ecosystem-Based Management of Marine Resources" in these proceedings (Vol. 2), doi:10.5270/OceanObs09.cwp.75.

55. O'Dor, R. \& Co-Authors (2010). "The Ocean Tracking Network" in these proceedings (Vol. 2), doi:10.5270/OceanObs09.cwp.66.

56. Hall, J., Harrison, D.E. \& Stammer, D. (Eds.) 2010. Proceedings of OceanObs'09: Sustained Ocean Observations and Information for Society Conference (Vol. 1), Venice, Italy, 21-25 September 2009, ESA Publication WPP-306, doi:10.5270/OceanObs09.

57. Francis, R.C. \& Hare, S.R. (1994). Decadal-scale regime shifts in the large marine ecosystems of the northeast Pacific: A case for historical science. Fisheries Oceanography 3, 279-291. 
58. Boesch, D.F., Field, J.C. \& Scavia, D. (2000). The potential consequences of climate variability and change on coastal areas and marine resources. NOAA's Coastal Ocean Program, Decision Analysis Series No. 21, pp. 163.

59. Field, J.G., Hempel, G. \& Summerhayes, C.P. (Eds.) (2002). Oceans 2020: Science, Trends and the Challenge of Sustainability. Island Press, Washington, D.C., pp. 365.

60. Chavez, F.P., Ryan, J., Lluch-Cota, S.E. \& Niquen, M. (2003). From Anchovies to Sardines and Back: Multidecadal Change in the Pacific Ocean. Science, 299, 217-221.

61. K. Sherman, L.M. Alexander and B.D. Gold (Eds.) (1993) Large Marine Ecosystems: Stress, Mitigation, and Sustainability, AAAS Press, Washington, D.C., pp. 376.

62. Longhurst, A.R. (1998). Ecological Geography of the Sea. Academic Press, NY, pp. 401.

63. Spalding, M.D., Fox, H.E., Allen, G.R., Davidson, N, Ferdana, Z.A., Finlayson, M., Halpern, B.S., Jorge, M.A., Lombana, A., Lourie, S.A., Martin, K.D., McManus, E., Molnar, J., Recchia, C.A., \& Robertson, J. (2007). Marine ecoregions of the world: a bioregionalization of coastal and shelf areas. Bioscience 57(7), 573-582.

64. Dietz, S., Hope, C., Stern, N. \& Zenghelis, D.A. (2007). Reflections on the Stern Review (1): A Robust Case for Strong Action to Reduce the Risks of Climate Change. World Economics, 8 (1), 121-168. (http://ssrn.com/abstract=981693)

65. Nicholls, R.J., Hanson, S., Herweijer, C., Patmore, N., Hallegatte, S., Jan Corfee-Morlot, Jean Chateau \& MuirWood, R. 2008, Ranking port cities with high exposure and vulnerability to climate extremes: exposure estimates, OECD Environment Working Papers, 1, University of Southampton, Southampton SO17 1BJ UK (http://www.oecd.org/dataoecd/16/10/39721444.pdf)

66. Ramcharan, R. (2007). Does the exchange rate regime matter for real shocks? Evidence from windstorms and earthquakes. J. International Economics 73, 31-47.

67. UNEP (2006). United Nations Environment Programme Finance Initiative (UNEP FI), Adaptation and Vulnerability to Climate Change: The Role of the Finance Sector, pp. 35 (http://www.unepfi.org/fileadmin/documents/CEO_brief ing_adaptation_vulnerability_2006.pdf

68. Brander, L.M., Van Beukering, P. \& Cesar, H.S.J. (2007). The recreational value of coral reefs: a meta-analysis. Ecological Economics 63, 209-218.

69. Hoegh-Guldberg, O., Mumby, P.J., Hooten, J., Steneck, R.S., Greenfield, P., Gomez, E., Harvell, C.D., Sale, P.F., Edwards, A.J., Caldeira, K., Knowlton, N., Eakin, C.M., Iglesias-Prieto, R., Muthiga, N., Bradbury, R.H., Dubi, A., \& Hatziolos, M.E., (2007). Coral reefs under rapid climate change and ocean acidification. Science, 318, 1737-1742.
70. Malone, T.C. \& Hemsley, J.M. (2006/2007). Developing the IOOS for improved management and mitigation of coastal inundation. Mar. Tech. Soc. J. 40 (4), 45-55). 